\title{
Rethinking the role of Track Two diplomacy in conflict resolution: the Democratic Progress Institute's Turkey programme
}

\section{Esra Dilek}

To cite this article: Esra Dilek (2021) Rethinking the role of Track Two diplomacy in conflict resolution: the Democratic Progress Institute's Turkey programme, Southeast European and Black Sea Studies, 21:2, 293-311, DOI: 10.1080/14683857.2021.1909291

To link to this article: https://doi.org/10.1080/14683857.2021.1909291

\section{Published online: 05 Apr 2021.}

Submit your article to this journal $\pi$

山 Article views: 161

Q View related articles 5

View Crossmark data \lceil

Citing articles: 2 View citing articles $ऍ$ 


\title{
Rethinking the role of Track Two diplomacy in conflict resolution: the Democratic Progress Institute's Turkey programme
}

\author{
Esra Dilek (iD \\ Department of Political Science, Bilkent University, Ankara, Turkey
}

\begin{abstract}
The article examines the Democratic Progress Institute's (DPI) Turkey program as a Track Two comparative consultation initiative applied in the case of Turkey's peace process regarding the Kurdish conflict, commonly known as the 'resolution/peace process' (2012-2015). Based on interviews with high- and middle-level actors participating in events organized by the DPI, the article investigates the extent the initiative reached its purposes of building capacities for peace through the dissemination of comparative insights on peacemaking and generating a joint understanding between the conflict representatives. While Turkish and Kurdish participants adopted comparative insights they gained from the DPI study trips and workshops, by learning lessons related to the negotiation process and practical matters, they partially sought to 'fit' those insights into their own perspectives and prior beliefs. The findings point to motivated reasoning and confirmation bias for issues that remained controversial throughout the public peace process in Turkey, mainly Disarmament-Demobilization-Reintegration (DDR) and transitional justice.
\end{abstract}

\section{KEYWORDS}

Turkey; Kurdish conflict; Track Two; Democratic Progress Institute; peace process; conflict resolution

\section{Introduction}

Track Two diplomacy is commonly understood as unofficial third-party interventions to a conflict with the purpose of building relationships and exploring new ideas for joint problem-solving (Fisher 2005). These initiatives generally involve influential representatives from the conflict communities participating in workshops in unofficial capacity along with impartial third parties who provide guidance, professional skills and knowledge. Track Two diplomacy aims mainly at resolving conflicts by encouraging communication, understanding, and collaboration towards shared problem solving (Diamond and Mcdonald 1996, 37). As a second main aim, these initiatives aim at transferring their impact to the official decision-making and/or the public level (Cuhadar 2009). From this viewpoint, Track Two diplomacy offers a range of activities that broaden official negotiations, such as problem-solving workshops, conferences, seminars, training, and dialogue groups.

CONTACT Esra Dilek esra.dilek@bilkent.edu.tr B Bilkent University, Bilkent, Ankara 06800, Turkey 
Early models of Track Two interventions were developed in the 1960s by scholarpractitioners such as Burton (1969) and Kelman (1979), addressing intractable conflicts such as the Cyprus and Israeli-Palestinian conflicts, respectively. Since then, Track Two diplomacy has acquired many forms involving a variety of actors directed towards diverse interactions with diverse purposes. One variation of Track Two diplomacy is comparative consultation, a model that aims at capacity building based on direct communication of experiences in a comparative manner by actors in one peace process experience to another (Mitchell 2020a, 3). This model is based on the assumption that comparative experiences can build capacities for peacemaking elsewhere through sharing of first-hand experiences and promoting positive and negative learning. As a Track Two diplomacy model, comparative consultation shares also the aim of transferring positive outcomes to the official negotiations and creating wider impact for the resolution of a conflict.

Based on interviews with high- and middle-level actors ${ }^{1}$ in Turkey's peace process for solving the Kurdish conflict (2009-2015), this article focuses on such a peace intervention methodology employed by the Democratic Progress Institute's (DPI) Turkey Program during 2011-2017. As a London-based non-governmental organization (NGO), the DPI was established in 2011, shortly before Turkey entered a process of public peace negotiations for resolving the Kurdish conflict in late 2012. The 2012-2015 process in Turkey was the first time that an open dialogue channel was created between conflict parties with the purpose of solving the conflict. The negotiation process was preceded by policies addressing democratic demands of the Kurdish community, known as the 'democratic opening', during 2009-2011. Simultaneously, secret negotiations were ongoing between 2006 and 2011, which were leaked to the media in 2011 (Kadığlu 2019). The peace process stalled in mid-2015 after disagreements over issues such as the timing of the Disarmament-Demobilization-Reintegration (DDR) process, possible third-party roles, issues pertaining to power-sharing, and the question of how and when to address transitional justice, including provisions of amnesty. During periods of stalling, the DPI organized comparative workshops on 'getting a process back on track' (Democratic Progress Institute 2015a, 2015b, 2016), aiming at sharing of experiences about how to revive stalled peace processes.

Turkish and Kurdish actors who were interviewed with regard to their perspectives on conflict resolution and peace process design were regular participants to DPI meetings during 2011-2017 and include (former) deputies from the main negotiation parties and middle-level influential actors such as civil society representatives, journalists, and academics, who held active ties with primary negotiators and with the grassroots level. Participants were asked about their opinions on peace process design with regard to different areas, including the negotiation process, political arrangements, security reform, and transitional justice. The open-ended interviews aimed at understanding Turkish and Kurdish actors' perspectives on peace process design and their expectations about the resolution/peace process in general. Findings pointed to the successful transfer of comparative insights with regard to practical and procedural issues at the individual level, i.e. in terms of how DPI meetings affected participants' perspectives on peacemaking. However, this transfer was limited with regard to controversial issues such as DDR and transitional justice. More specifically, comparative insights regarding controversial issues were expressed with the purpose of supporting and confirming priors. 
The article is organized as follows: The next section provides an overview of the main characteristics and functions of Track Two diplomacy as a conflict resolution initiative with a focus on comparative consultation and transfer mechanisms. The second section describes the DPI Turkey Program with regard to its structure and its work during 2011-2017. The third part discusses findings from open-ended, semi-structured interviews with Turkish and Kurdish participants at DPI meetings and assesses the extent the initiative was successful in reaching its objectives.

\section{Main characteristics of Track Two diplomacy and comparative consultation}

Track Two initiatives are designed as unofficial interactions aiming at building relationships, changing perceptions and producing new ideas for conflict resolution (Allen and Sharp 2017). The term 'Track Two Diplomacy' was first coined by Joseph Montville in 1981 to denote dialogue processes that were taking place outside of official negotiations in the field of conflict resolution (Davidson and Montville 1981; Jones 2015). Initiatives directed towards unofficial interactions have been formed based on various philosophical standpoints commonly focusing on how contact might have a positive impact on conflict resolution by transforming relationships and creating new ideas. Some variations of second track diplomacy include interactive conflict resolution (Fisher 1997), interactive problem-solving workshops (Azar 1990; Kelman 2006), and third-party consultation (Fisher and Keashly 1991).

Track Two diplomacy complements official diplomacy by providing opportunities for communication and understanding among actors that hold differing views on a conflict. As Davies and Kaufman note, Track Two diplomacy 'can inject new insights and ideas into the official process, help to humanize the "enemy", reduce tensions and misunderstanding [...] and build public support and political will for peacemaking' $(2003,2)$. Such initiatives are different from official diplomacy as they are not binding and do not aim at reaching a negotiated solution regarding a conflict. Rather than focusing on agenda issues, these meetings help participants to focus on their overall relationships and to reflect upon their own and their opponents' experiences on the conflict (Saunders 2000, 256).

Participants are often politically influential members of their communities and are chosen based on the need to consider both official impact (transfer to Track One) and wider societal impact (Pearson D'estrée 2009). Track Two initiatives are organized and facilitated by third parties, typically scholar-practitioners who are experienced in conflict resolution, are knowledgeable about international conflict and regional dynamics and adopt a facilitative role (Kelman 1996, 506). NGOs have been increasingly active as third parties in organizing and facilitating Track Two diplomacy (Chigas 2014). Third parties facilitate 'assisted brainstorming' since, if conflict parties are left to themselves it is likely that the process would lead to further polarization (Chataway 2002, 166). Facilitated by the third party, during the meeting participants are encouraged to deal with the conflict analytically and not polemically (Kelman 1997, 214) while the generation of new ideas is done by the participants themselves (Kelman 1997; Mitchell and Banks 1996) and not by the third party facilitator.

Track Two initiatives are diverse in terms of their structure and aims. One main distinction is between Track One-and-a-half, Track Two, and Track Three diplomacy 
that present differences in terms of the profile of participants and the main aims. Track one-and-a-half diplomacy includes officials in their private capacities, retired officials who retain influence with the leadership, trusted friends of the leadership, and influential citizens and opinion shapers (Jones 2015, 123). Track One-and-a-Half combines the strengths of Track One and Track Two diplomacy since involving official political actors in unofficial capacity strengthens the initiatives' capacity for transferring outcomes to the official negotiations while allowing for non-binding interaction (Nan 2005). Participants to Track Two diplomacy include civil society leaders, conflict resolution experts, influential citizens and opinion shapers (Jones 2015, 123). Such actors retain connections both with the official decision-makers and the public at large. Track Three diplomacy involves the grassroots level with the participation of local actors and including 'people-to-people' activities (Chigas 2007, 2014). Such initiatives are aimed towards achieving wider societal change. Track Three diplomacy is mainly based on the conflict transformation perspective (Jean Paul Lederach 1997).

This variety is also reflected in the aims of the different Track Two initiatives. Agha et al., for example, distinguish between 'soft' Track Two exercises directed towards improving understanding for each side and promoting exchange of views, and 'hard' Track Two exercises that aim at achieving a breakthrough in the efforts to solve a conflict $(2003,3)$. This parallels the distinction between 'process-focused' and 'outcome-focused' Track Two initiatives (Cuhadar and Dayton 2012, 158), where process-oriented initiatives are directed towards transforming adversarial relationships between parties while outcome-oriented initiatives aim at positively influencing the outcome of official negotiations. In terms of extending the impact of Track Two diplomacy outside of the workshops, a process known as 'transfer', three main directions can be identified: towards the political decision-making (also called 'upwards' transfer), towards the public and political constituencies (also called 'downwards' transfer), and towards the actual negotiators (Fisher 2005, 6). Another direction is transfer into other Track Two initiatives (also called 'lateral' transfer) (Cuhadar 2009). In general terms, micro-objectives of such workshops are directed towards changing mutual conflictual perspectives and reaching mutual understanding of political ideas (Rouhana 2000, 297). Macro-goals are directed towards influencing the dynamics of the conflict by, for example, transforming societal beliefs and influencing decision-makers (Rouhana 2000, 297).

As a type of Track Two intervention, comparative consultation rests on the sharing of expertise and experiences of comparative peacemaking. As proposed by Mitchell (2020a), comparative consultation is a subtype of Track Two diplomacy with specific characteristics, most important being the focus on the analysis of a comparative case through firsthand accounts of the peace process. Participants to such Track Two initiatives include international and local experts along with representatives from the conflict communities. These experts provide first-hand accounts about back channel negotiations and procedural issues regarding peacemaking.

This model is based on learning lessons from 'other cases' that have completed or are in the process of completing peace negotiations, based on analogical reasoning. Insights from the field of negotiation teaching have showed that analogical reasoning based on comparisons facilitates knowledge transfer (Gillespie et al. 1999; Lowenstein et al. 2003). Analogical learning has also shown to perform better in transferring knowledge compared to didactic and information-based learning (Nadler et al. 2003). Learning by analogy is different from 
experiential learning models applied in some Track Two diplomacy interventions where participants develop skills and awareness through role plays, simulations, lectures, and discussion (Diamond and Fisher 1995, 289). Comparative consultation involves communication of experiences by local and international actors who have personal experience with peacemaking and does not focus on the conflict that the intervention is directed to. The model then leaves ample space for the participants from conflict communities to draw lessons that they consider as being relevant for their own conflict, 'filtering' externally generated policy ideas to the local environment, or in other words, translating outside concepts to the local context (Kaye 2007, 23). At the same time, comparative learning is seen as enhancing the potential for policy transfer through the dissemination of practicerelevant knowledge (Mitchell 2020b). Lessons can be categorized into three: process lessons regarding the broad nature of a peace process; technical lessons regarding specific conflict resolution techniques (such as DDR); and actor lessons as lessons learned by actors in a peace process (Mitchell 2020b).

In the comparative consultation model that is based on sharing expertise and experiences, the position of the international and local experts is important. Third parties facilitating Track Two initiatives possess referent, expert, and informational power. Referent power is derived from the value that parties place on their relationship with the third party (Jones 2015, 109). Informational and expert power, on the other hand, are derived from third party's access to specialized information and third party's expert knowledge, respectively (Jones 2015, 109). Informational and expert power types are most crucial for Track Two comparative consultation that is based on the sharing of comparative expertise with the purpose of building capacities for peace elsewhere. One main specificity of this model is that the facilitator third party makes use of both international and local expertise, by involving international and local participants into the meetings and facilitating the sharing of knowledge and lessons that might be relevant for representatives of conflict communities from around the world.

\section{Method}

The article rests on open-ended in-depth interviews with participants to the DPI Turkey Program at various capacities in the period between 2011 and 2017. A total of 16 participants of the events organized by the DPI, including study trips outside of Turkey and also roundtables both abroad and in different cities in Turkey, were interviewed for the purposes of this article. ${ }^{2}$ Out of the sixteen interviewees, four have been members of DPI's Council of Experts, a group of Turkish and foreign specialists that support the work of the DPI on a regular basis. The remaining 12 interviewees have actively participated in study trips abroad and in roundtables and other meetings in different cities in Turkey and abroad. Also, the program's a DPI representative from the Turkey Program was interviewed for the details of the organization's work in terms of its structure and its activities on Turkey. The interview data were corroborated with DPI meeting reports available on the organization's website. During the period 2011-2017, a total of 36 reports were published on the organization's website. Each report was analysed in terms of the participants and the topics and themes of the meetings. 


\section{The Democratic Progress Institute's Turkey program}

The DPI is a London-based NGO that was established in 2011 by a Turkish conflict resolution and peacebuilding expert who has done previous work on the Kurdish issue with focus on the area of human rights. ${ }^{3}$ Since its establishment, the DPI Turkey Program has organized dense Track Two diplomacy activities in the form of study visits, workshops, and roundtables with the participation of high- and middle-level actors from Turkey. The organization has also produced regular reports and research papers on conflict resolution and peace processes, as summarized in Table 1.

As it is noted in the foreword of the DPI reports, the organization adopts an intervention strategy based on the provision of expertise and comparative studies of relevant peacemaking experiences (Democratic Progress Institute 2012):

We focus on providing expertise and practical frameworks to encourage stronger public debates and involvements in promoting peace and democracy building internationally. [...] DPI also aims to support and strengthen collaboration between academics, civil society, and policy-makers through its projects and output. Comparative studies of relevant situations are seen as an effective tool for ensuring that the mistakes of others are not repeated or perpetuated. Therefore, we see comparative models of peace and democracy building to be central to the aim of our achievements and objectives.

The focus of the organization on comparative studies indicates that a 'capacity builder' approach is adopted with the purpose of contributing to conflict transformation (Cuhadar and Dayton 2012). Accordingly, building conflict management skills and thus empowering individuals is seen as central for peaceful change. By providing comparative studies of peace processes around the world, the DPI offers a platform for sharing positive and negative experiences that might be of relevance for peace processes elsewhere. The model provides insights predominantly about process issues rather than focusing on issues related to the substance, i.e. the history of conflict and the content of the negotiation. This model is seen as important for broadening analytical approaches to conflict resolution by considering possible solutions to intergroup conflicts with differing backgrounds and dynamics.

DPI organized a number of comparative study visits outside of Turkey and roundtables in Turkey with Turkish and Kurdish participants. Study visits were organized to four countries since the establishment of the organization in 2011: Northern Ireland, South Africa, Colombia, and the Philippines. ${ }^{5}$ Of these countries, Northern Ireland and South Africa experienced peacemaking during the 1990s and are frequently analysed as successful peace processes providing valuable insights regarding issues such as

Table 1. DPI turkey program events and publications, 2011-2017

\begin{tabular}{cccccc}
\hline & \multicolumn{2}{c}{ Events } & & \multicolumn{2}{c}{ Publications } \\
\cline { 2 - 3 } \cline { 5 - 5 } Years & Comparative Study Visit & Roundtable & & Report & Research Paper \\
\hline 2011 & 1 & 1 & 0 & 0 \\
2012 & 1 & 3 & 7 & 13 \\
2013 & 4 & 4 & 6 & 10 \\
2014 & 4 & 5 & 5 & 9 \\
2015 & 3 & 4 & 5 & 13 \\
2016 & 3 & 4 & 7 & 19 \\
2017 & 1 & 6 & 5 & 5 \\
\hline
\end{tabular}


inclusivity, the role of third parties, the role of civil society, and transitional justice processes (Darby 2008; Hazleton 2013). The peace processes in Colombia and the Philippines were ongoing at the time when DPI organized Track Two diplomacy study visits. During 2011-2017, most visits were made to Northern Ireland and the United Kingdom due to practical considerations ${ }^{6}$ and the rest of the study visits were limited in number due to logistical concerns and expenses.

Each study visit lasted several days and encompassed an intensive program including roundtable meetings, seminars, private tours, receptions, and meals with participants from Turkey and from the country of visit. Involving formal meetings and informal gatherings, the study visits provided a platform for socialization among participants, ${ }^{7}$ contributing to in-group socialization and social cohesion (Paffenholz and Spurk 2010, 67). Each study trip outside of Turkey involved 15 to 22 participants from Turkey while the number of participants in roundtables that were organized in different cities in Turkey reached $50^{8}$ at times. Participants from Turkey included party members and deputies in unofficial capacity and also civil society actors, academics, journalists, and intellectuals. High-level actors such as deputies and party members shared summary reports with their parties upon completion of each study trip. ${ }^{9}$ Also, participants (especially participants from the media) shared the perspectives discussed in the events through media outlets and opinion pieces, ${ }^{10}$ adding to the knowledge sharing process. In this way, insights from the study trips and roundtables were shared both upwards with decision makers and downwards with the public.

The organization became the meeting point for actors from different political sides in Turkey, including the Justice and Development Party (JDP) and the pro-Kurdish People's Democracy Party (PDP) (the main negotiating parties) and the Republican People's Party (RPP) (the main opposition party). Political actors from the Nationalist Movement Party (NMP), the ultra-nationalist party in Turkish politics, while being invited to the meetings and activities organized by DPI, never participated. As a common characteristic of Track Two diplomacy, the organization recruited participants based on the assumption that contact between adversarial groups will help improve relations and break prejudices. In the words of an interviewee from the DPI Turkey Program:

We used to call persons with strong disagreements on purpose, because we have this principle, to talk on the issue with people who are most far to the issue, those who would not speak to each other on other occasions, in order to break down the prejudices if possible, and more importantly, to get them into dialogue with each other with the expectation that communication would help break prejudices by itself. ${ }^{11}$

The organization's work is divided into different focus areas of activity including facilitating collaborative expertise sharing, building capacity through mentoring, and strengthening knowledge through assessment and analysis. ${ }^{12}$ The DPI provides expertise through its Council of Experts, composed of academics, journalists, independent experts, NGO leaders, and professionals from Turkey and other countries. Out of 13 experts from Turkey, six were previously members of the Wise People Commission ${ }^{13}$ (WPC) that was officially formed in April 2013 as part of the public peace process. Foreign experts include prominent conflict resolution practitioners such as Jonathan Powell who was the British Government's chief negotiator in Northern Ireland during 1997-2007, and Roelf Meyer 
who was the South African government's chief negotiator in constitutional negotiations in 1993. Former politicians and diplomats including Bertie Ahern, the former Prime Minister of Northern Ireland; Dermot Ahern, former government minister of the Northern Irish Parliament; and other former European Union (EU) and British diplomats are also part of the Council of Experts. Furthermore, each study visit included local experts from the comparative case who provided first-hand experiences about the negotiation process in their own countries and shared details about back channel negotiations. During 2011-2017, members of the Council of Experts were regular participants in study visits and roundtables in Turkey.

As it is noted on its website, the DPI seeks to achieve collaborative expertise sharing through a model whereby (Democratic Progress Institute 2018):

The participants are encouraged to focus their attention on commonalities with other conflicts, rather than their own differences. This unique model helps establish an environment in which potential solutions can be explored with conflict transformation experts who have practical experience of relevant subjects, and in which bridges are built between different sides of a conflict.

The DPI Turkey Program representative also highlighted this point during a personal communication, noting 'We never talk about Turkey [in our meetings]. The best way to think about Turkey is to discuss other cases'. ${ }^{14}$ As a main characteristic of comparative consultation (Mitchell 2020a), this strategy proved crucial in opening up space for discussing issues related to conflict resolution and peace negotiation processes in general and moving beyond divisive boundaries among participants that come from differing positions and viewpoints on the conflict in Turkey. The next section investigates the extent the comparative model provided by the DPI led to the transfer of peacemaking insights among Turkish and Kurdish participants and the generation of a common perspective on the conflict in Turkey.

\section{Turkish and Kurdish actors' insights on peace process design}

To what extent did the DPI Turkey program initiatives reach their objectives of transferring comparative insights to participants and increasing mutual understanding of the conflict? The following analysis addresses this question with the purpose of extending our understanding of Track Two diplomacy in a case where the comparative consultation model was used, from the viewpoint of participants. The interview findings are discussed under three main themes: the transfer of process-focused and actor knowledge; insights about continuity of negotiations and resilience; and the limits of transfer with regard to controversial issues related to DDR and transitional justice.

Interviewees adopted comparative perspectives mainly from the Northern Irish and South African peace processes. Colombia and the Philippines were referred to as comparative cases only minimally. Interviewees who were asked about their selection of Northern Ireland and South Africa as primary cases of reference, discussed these cases as successful and completed negotiation processes that led to the resolution of long-lasting conflict. Therefore, their perception of these cases as successful and completed consisted a primary reason for their case selection. The structure of the Council of Experts, composed of political actors that held important positions in the South African and 
Northern Irish negotiations, can be seen as an additional main reason for interviewees' extensive references to insights from those cases. As discussed below, this became apparent through references to personal contact and actor lessons that interviewees mentioned.

\section{Transfer of process-focused and actor knowledge}

In creating parallels with other peace processes, interviewees mentioned predominantly insights about process rather than substance. Interviewees commented on substance issues only to support a perspective about process. For example, a Kurdish interviewee commenting on the need to design an inclusive peace process, pointed to commonalities between minority majority relations in Northern Ireland and Turkey. ${ }^{15}$ The focus on process can also be easily discerned from the fact that the two main cases of comparison, Northern Ireland and South Africa, have substantially different conflict backgrounds with the Turkish case and with each other. Several interviewees commented that although each conflict is sui generis, processes for solving conflicts might present parallels and provide insights for conflict resolution processes elsewhere. Multiple interviewees noted that learning not only from the successes but also from the failures of others is important for any effort of peacemaking.

A main issue discussed with regard to process is related to the question of who should be included in the peacemaking process. Most comments on this process issue derived from the Northern Irish peace process. These references mainly involved discussions regarding the inclusion/exclusion of some fractions (such as armed groups) from the negotiation process, and the question of whether and how to include actors outside of the primary parties to the conflict, such as the civil society. One common argument regarding inclusivity is that all major political fractions should be included in the negotiation process with the purpose of securing a more inclusive and thus successful process where the concerns of all parties are addressed (Blaydes and De Maio 2010).

For example, a WPC member stated that 'We see that in the case of Northern Ireland, you need to consider other groups, too, while you try to solve the problems of one group. Otherwise, you might create new problems'. ${ }^{16}$ This view emerged in several interviews as prominent for the success of the negotiation process. Many interviewees underlined the need for including not only armed group representatives but also all major political fractions in the negotiation process so that to achieve a commonly agreed upon framework that will lead to sustainable conflict resolution.

Another common issue that emerged with regard to inclusivity is the inclusion of societal segments beyond the primary decision makers. For example, a deputy from the pro-Kurdish party expressed this view by referring to Northern Ireland as being a successful example where the civil society and the Church were included in the peace process. ${ }^{17}$ From a similar standpoint, another interviewee argued that inclusivity means engaging actors below the formal decision-making level to the process as this will help address the concerns of the society at large. The interviewee pointed to the need to gradually expand the negotiation circle by including actors beyond the primary negotiating parties. She commented that 'We see that similar processes took place in other countries too, such as Northern Ireland and the Philippines. There is need for (involving) other circles, there need to be concurrent circles'. ${ }^{18}$ 
Actor lessons were visible in interviewees' repeated references to personal contact. Many interviewees mentioned personal communication with actors from other cases while discussing a specific issue or process related to the peace process in Turkey or peace processes in general. In these references, interviewees pointed to how actors/experts from other cases communicated their own lessons of peacemaking. For example, a former Justice and Development Party (JDP) deputy stated that:

The then minister in charge (in Northern Ireland) told me in a meeting in Istanbul that if we had decided to proceed in transparent manner from the beginning [of the negotiations], we would have lost government power. [...] The South African minister said the same thing. This is the nature of a peace process. ${ }^{19}$

Participants from all sides and levels underlined personal contact and related actor lessons. For example, a JDP deputy pointed to the importance of leaders for adopting the idea of inclusive negotiations (referring to the inclusion of all major stakeholders in the peace negotiation process) as a principle, by referring to a personal communication with the Irish Prime Minister. ${ }^{20}$ A deputy from the People's Democracy Party (PDP) referred to Jonathan Powell's comment in a personal communication, who mentioned that 'when you look at other cases and for example when you examine our case, focus on our mistakes rather than on our successes', underlining how important this is for learning lessons from other cases. ${ }^{21}$ A WPC member and former advisor to the Prime Minister supported his view about the importance of a third party negotiator by referring to a personal communication with George Mitchell, the U.S. Senator appointed in the Northern Irish negotiations. ${ }^{22}$ A deputy from JDP supported the view that back-channel non-transparent communication between the negotiating parties is needed at certain stages of a process by referring to his personal communication with relevant actors from the South African and Northern Irish processes. ${ }^{23}$ It is seen that participants from all sides valued personal contact in their evaluations of how to resolve a conflict and actor lessons about how to proceed in a peace process.

\section{Insights about the continuity of negotiations and resilience}

A main theme commonly expressed by interviewees is related to the continuity of negotiations and the idea of being resilient despite setbacks. Multiple interviewees referred to different aspects of the Northern Irish and South African peace negotiation processes by pointing to the importance of being resilient despite risks and uncertainties that might come up during the negotiation process. This revealed the concern with sticking with the peace negotiation framework over other alternatives (such as the continuation of conflict).

A deputy from the pro-Kurdish People's Democracy Party commented on how both in the South African and in the Northern Irish experience main actors in the negotiation process remained loyal to the aim of reaching a political solution to the conflict. ${ }^{24}$ A journalist and member of the Wise People Commission (WPC) pointed to the issue of continuity by arguing how in the South African case the process of dialogue continued despite major tragic incidents such as the Soweto massacre that took place in 1976. The interviewee underlined that while official contacts were interrupted, the dialogue process continued at the backchannel. The interviewee mentioned that he received this 
information from the South African Minister of Defence who was in charge of the negotiations in a personal communication that they had during one of the DPI Turkey meetings. ${ }^{25}$ Another interviewee- academic and member of the WPC- made reference to the ongoing Colombian peace process with regard to the continuity of the negotiations. He mentioned that despite the stalling of negotiations between the Colombian government and the FARC multiple times, eventually a peace agreement was signed. The interviewee further shared his opinion that he expected that this would be the case for Turkey, too. ${ }^{26}$

From a similar viewpoint, several references were made regarding the duration of a peace process; a recurrent theme being that peace processes last long and therefore the sides should be patient for reaching an agreement. ${ }^{27}$ This view points to the idea that after signing an agreement; the implementation of the process might take long. Therefore, parties need to be aware of the need to be resilient even in the post-agreement phase. Another issue discussed in relation to the issue of the continuity of negotiations despite setbacks is related to the role of third parties in the negotiation process. Several interviewees pointed that third party involvement is crucial for the continuation of a process at times of deadlock. A WPC member and journalist, for example, pointed to Northern Ireland and South Africa as examples where 'when the process stifled, when they were confused on what to do they let a third actor to engage. ${ }^{28}$

One explanation for the prominence of the resilience theme can be that participants to Track Two initiatives in general and to the comparative consultation events organized by the DPI in particular are already moderate individuals who are supportive for a political solution to the conflict and thus the continuation of the negotiation framework. Another explanation for the prominence of the resilience theme is the timing of the interviews. The interviews took place during the second half of 2015 when official negotiations were stalled. During this period, the DPI organized several roundtables on how to get the process back on track that may have resonated with interviewees' need for establishing analogies with other comparative cases. The prominence of the resilience theme confirms the overall observation that the DPI interventions succeeded in disseminating comparative insights about practicalities that may help keep the negotiation framework despite setbacks.

\section{Disarmament-Demobilization-Reintegration (DDR) and transitional justice: confirming priors}

Two issues that remained controversial during the public peace process, DDR and transitional justice, emerged as controversial in the interviews. Interviewees who commented on these two areas adopted lessons that confirmed their priors, pointing to motivated reasoning and confirmation bias (Druckman 2012; Kunda 1990). Interviewees made selective references to comparative insights, by even drawing contradictory lessons from the same comparative case.

DDR is generally viewed as one of the most controversial aspects of peace negotiations. This is related to the difficulty of negotiating the process of disarming armed fractions (Knight and Özerdem 2004). During the resolution/peace process (2013-2015), controversies surrounding DDR were mainly related to the timing and process of disarmament. The process stalled after the government accused the armed group of 
not completing the first phase of disarmament. The Kurdish side responded to this accusation by criticizing the expectation for disarmament before other democratic demands were met. Furthermore, during the peace process, discussions on DDR were highly embedded with the positions of the actors regarding the conflict in Turkey. Previous research identified two main approaches towards the Kurdish conflict in Turkey that can be linked directly to two different positions on DDR; a rights-based approach and a military approach (Dilek 2019). A military approach to the conflict is based on a securitized understanding and regards DDR as a prerequisite for any possible political solution to the conflict. A rights-based approach sees the root causes of the conflict in the lack of cultural rights and systematic discrimination and regards DDR as a final step of a peace process.

Paralleling the views of primary actors in the negotiation process, interviewees closer to the securitized approach to the conflict supported the prioritization of the DDR in the resolution/peace process. In the opposite direction, actors closer to the rights and recognition approach supported the view that DDR should follow in later parts of negotiations by making references mainly to the case of Northern Ireland. For example, a deputy from the pro-Kurdish People's Democracy Party referred to Northern Ireland, arguing that the reason why the process could not begin earlier is that the John Major government had posed disarmament as a prerequisite for the process. ${ }^{29}$ The interviewee expressed this view in support of the pro-Kurdish view that disarmament should itself be a point of negotiation and not a precondition for the start or continuation of negotiations.

From a similar perspective, another interviewee, WPC member and human rights activist expressed the view that disarmament is the final stage of a peace process. To support this view, he referred to the Northern Irish case by arguing that IRA's disarmament was completed at the end of 10 years. Accordingly, by creating parallels between the disarmament of the IRA and the Kurdish conflict in Turkey, the interviewee pointed to the Kurdish side's negotiation demands as being consistent with the logical flow of a peace process. From this viewpoint, the Kurdish side's demands for justice first and disarmament as the last stage fit well with what a successful peace process would look like. $^{30}$

In line with the military approach, a JDP deputy referred to the DDR process in the case of IRA in Northern Ireland by criticizing the Kurdish actors' stance. The interviewee accused the Kurdish side of drawing the 'wrong lessons' from IRA's disarmament process and supported the government's expectation for 'disarmament first' by arguing that the relations between the armed group and the government are different in the two cases (Northern Ireland and Turkey). ${ }^{31}$ From an opposite perspective, a former JDP deputy from Kurdish origin who is a civil society actor active in the area of human rights argued that a long-term disarmament process is needed and it should be realized only after political, administrative and economic reforms are fulfilled. ${ }^{32}$ As these perspectives reveal, participants adopted ideas on DDR from international experiences by fitting them to their own positions on the issue under discussion.

A similar tendency was observed regarding transitional justice. In the peace negotiation process in Turkey, transitional justice based on restorative mechanisms emerged as a primary demand by the pro-Kurdish side. The reason for the prominence of transitional justice and especially of the issue of amnesty and of a truth commission is related to 
the asymmetric position of the Kurdish side and the position of the Kurdish insurgency. As expected, pro-Kurdish actors demanded a transitional justice mechanism that would promote restorative justice beyond retribution and punishment. For example, a deputy from the People's Democracy Party noted that it would be good to have a commission that will have the authority to amnesty, similar to that in South Africa, one that would be authorized to listen to everyone, to have access to all information and in return to have the authority to forgive the wrongdoer. ${ }^{33}$ Other interviewees also commented on how the formula of amnesty applied in Northern Ireland was a successful transitional justice mechanism since it provided the security guarantees needed for the IRA leaders to accept disarmament. ${ }^{34}$

On the other hand, the Northern Irish case was referred to support the opposite idea of excluding any kind of truth seeking as part of transitional justice. A journalist and WPC member supported this view by arguing that 'In Northern Ireland, they gave up on this idea. They said, "if we attempt to face the truth, we will revive all the pain we went through and our wounds will relapse". ${ }^{35}$ In the same direction, another journalist and WPC member stated: 'What I saw in Northern Ireland is that, there were difficulties in terms of evidence and in terms of creating links between perpetrators and evidence, so there were problems as there was lack of clear and just account of the crimes committed'. ${ }^{36}$ As a third example, a civil society actor and WPC member stated:

We examined the Irish case and there, you know, the issue of truth was left to the end and currently still the process related to the 2014 agreement is continuing and there are still walls, still neighbourhoods are divided, people have doubts towards each other, and the families of the victims still have problems. ${ }^{37}$

Overall, DDR and transitional justice emerged as controversial topics and interviewees commenting on them sought to fit comparative insights to their already existing perspectives. Interviewees confirmed their prior beliefs and positions about the timing of the disarmament and demobilization process, about whether restorative justice mechanisms such as truth seeking is suitable for successful conflict resolution, and about amnesty being important for offering the security guarantees needed for disarmament.

\section{Discussion}

Turkish and Kurdish actors participating in the unofficial initiatives organized by the DPI Turkey Program discussed part of their insights on peace process design through their perspectives on how political actors in other countries have responded to similar situations. They adopted insights from comparative peace processes mainly with regard to process issues and practicalities. Insights from interviews revealed that the DPI program enabled participants to learn lessons that they deemed important by listening to local and international experts who shared their first-hand experiences on conflict resolution. Participants' references to personal communication revealed the importance of this structure for the transfer process. First-hand experiences communicated by international and local experts broadened participants' perspectives on possible pathways for resolving conflicts. Participants then reflected upon those perspectives through their own lens.

The comparative consultation model offered by the DPI was successful in disseminating comparative insights with the purpose of building capacities for conflict resolution. 
This was apparent from Turkish and Kurdish interviewees' frequent references to personal contact and to specific process and actor lessons they 'learned' through their participation to the DPI meetings. Interviewees expressed both positive lessons in the form of a lesson that can be adopted for the Turkish case, and also negative lessons, about what to avoid. Most participants reflected upon how the suspension of public negotiations did not mean that backchannel processes were also suspended. Similarly, different participants made references to different process and technical issues, such as the inclusion of fractions beyond primary negotiating parties into the negotiation process, the role of third parties in peacebuilding, and the issue of whether negotiations should be transparent or not, by referring to how these processes worked in the comparative cases.

Interviewees debated two issues that remained controversial during the resolution/ peace process, DDR and transitional justice, in ways confirming their already existing perspectives. Interviewees commenting on these two issues showed motivated reasoning, referring to the tendency to seek out information that confirms prior beliefs and thoughts. Previous research in cognitive psychology has shown that people motivated to arrive at a particular conclusion attempt to justify their desired conclusion based on accuracy and directional goals (Kunda 1990). Accuracy motivations refer to the desire to be 'right' while directional motivations refer to the desire to defend or protect a predetermined attitude. Individuals driven by directional goals will use interpretational strategies that increase the possibility of understanding the information in accordance with prior beliefs (Beaekgaard et al. 2019, 1119). Multiple participants' tendency to draw lessons from the same case by interpreting it in different ways can be seen as fulfiling directional goals. Interviewees understood and interpreted information regarding DDR and transitional justice in accordance with their already existing perceptions on these processes. Participants in this way showed an effort to 'fit' and 'filter' external ideas to local context (Kaye 2007, 24) and more specifically, to their own perspectives within the local context. This effort reflected the variety of the perspectives regarding the Kurdish conflict and its root causes, including security versus democracy and rights-oriented approaches prevalent both at the grassroots and the decision-making levels (Dilek 2019; Ulug and Cohrs 2016, 2017). While the interview process for this research did not primarily consider such understandings, the existence of competing viewpoints was reflected in the interviews.

\section{Conclusion}

Track Two initiatives are regarded as complementary to official negotiations as they aim at transforming relationships and generating new ideas for conflict resolution. This article focused on a Track Two initiative, the Democratic Progress Institute's (DPI) Turkey Program adopting a comparative consultation approach, with regard to its potential in broadening our understanding of second track diplomacy. The DPI provided a platform for sharing comparative experiences on conflict resolution with high- and middle-level actors in Turkey's peace process for solving the Kurdish conflict through a model that is based on comparative consultation. The structure of comparative consultation meetings, focusing on a comparative case rather than the participants' own conflict, left the room for participants in the DPI meetings to selectively learn lessons that 'fit' their domestic positions on the Kurdish conflict in Turkey. 
As a Track Two initiative, the work of the DPI's Turkey Program formed a channel through which Turkish and Kurdish middle- and high level-actors engaged with comparative insights on peace processes through meetings, comparative study visits, and roundtables and also through reports and research papers. In line with classical Track Two diplomacy, the DPI program provided the platform for socialization for participants from Turkey. Participants coming from a variety of backgrounds and representing different perspectives on the conflict were able to interact in an informal environment. The organization adopted a capacity-builder approach to conflict resolution. The DPI provided a platform for the sharing of comparative experiences of peacemaking, shared by local and international experts. International and local experts shared first-hand experiences of both front and back channel negotiations and participants were able to draw process lessons, technical lessons, and actor lessons regarding peace processes.

Interviews with participants to the DPI Turkey program study visits outside of Turkey and meetings at various cities in Turkey revealed two main findings. First, the initiatives were successful to a certain extent in disseminating comparative insights and therefore in building capacities for peacemaking. Turkish and Kurdish participants to the study visits and events in Turkey referred to lessons they 'learned' about resilience and the continuity of negotiations in periods of crisis, valued personal contact and actor lessons, and developed insights on inclusivity and practical matters regarding specific processes such as DDR and transitional justice. Second, interviews revealed that transfer did not lead to the formation of a common perspective on the resolution of conflict, especially for issues that remained controversial during the public negotiations. Participants sought to fit their comparative insights about DDR and transitional justice into their already existing perspectives and supported their prior beliefs through interpreting lessons they learned from experts for confirming their priors.

While limited to the Turkish case and to a single (but continuous) Track Two initiative, findings in this research might be extended to wider discussions on the effectiveness of Track Two diplomacy in reaching its micro- and macro-objectives. Future research might address how comparative consultation and expertise sharing might contribute to reframe the conflict as a shared problem solving that can be solved collaboratively (Diamond and Mcdonald 1996), and help overcoming priors regarding specific issues within a peace process. Furthermore, this study focused on the effectiveness of comparative consultation at the individual level, in terms of how ideas and lessons discussed in DPI meetings affected participants' views on peacemaking. Further research investigating transfers to official negotiations (Track One) and to the wider societal level will contribute in understanding the wider impact of such initiatives as a peace intervention strategy.

\section{Notes}

1. The term 'middle-level actors' is adopted from Lederach's (1999) distinction between different levels of actors that are active in a peace process. The middle-level includes community representatives, influencers, civil society representatives, journalists, academics and other groups that sustain relationships with the decision-making level and the grassroots level. 
2. The sample for this study draws from a larger sample of middle- and high-level Turkish and Kurdish actors interviewed as part of a $\mathrm{PhD}$ project titled Reconsidering the Hybridity Debate In Peacebuilding: The Case of Turkey's Peace Process for Solving the Kurdish Conflict (2009-2015).

3. Information on DPI's work structure and activities is derived from http://www.democraticprogress.org/our-focus-areas/ (last accessed 11 July 2020).

4. The table was prepared based on information collected from the official website of the DPI. The number of comparative study visits and roundtables were calculated by the author based on the meeting reports and the news pieces available on the website.

5. Study trip to a fifth country, Germany, was organized in 2013 with the purpose of investigating the political system of the country. Information on the study visits and summary reports of the meetings are available on DPI's website at http://www.democratic progress.org/category/publications/reports/ (last accessed 11 July 2020).

6. Interview with DPI officer, number 16.

7. This view was expressed by several interviewees and also by the DPI Turkey program officer.

8. Most of the reports of study trips and roundtables include the list of the participants to the event. This information is based on the overview of the reports on the website of the organization.

9. Interview with DPI officer, number 16.

10. Participants are allowed to share the views discussed in the meetings under Chatham House Rule, i.e. without citing the person who expressed the view.

11. Interview with DPI Turkey officer, number 16.

12. Information is available at http://www.democraticprogress.org/our-focus-areas/ (last accessed 11 July 2020).

13. Referring to a commission of 63 members established in April 2013 with the purpose of convening meetings with the public to discuss expectations from the peace process. The commission was composed of middle level actors such as civil society representatives, journalists, academics, and intellectuals and was divided into seven groups that organized activities and meetings at the seven geographical regions in Turkey.

14. Interview number 16.

15. Interview number 15 .

16. Interview number 6 .

17. Interview number 9 .

18. Interview number 7 .

19. Interview number 10 .

20. Interview number 10 .

21. Interview number 12.

22. Interview number 8 .

23. Interview number 10 .

24. Interview number 15.

25. Interview number 11.

26. Interview number 5 .

27. Interview number 10 .

28. Interview number 11.

29. Interview number 12 .

30. Interview number 2 .

31. Interview number 13.

32. Interview number 1 .

33. Interview number 12.

34. Interview number 25 .

35. Interview number 11.

36. Interview number 7 .

37. Interview number 4 . 


\section{Disclosure statement}

No potential conflict of interest was reported by the author(s).

\section{Notes on contributor}

Esra Dilek is a Lecturer at Bilkent University in Ankara, Turkey. Her research focuses on peace and conflict studies, international norms, and negotiation processes. She is currently carrying out research on comparative peace processes.

\section{ORCID}

Esra Dilek (D) http://orcid.org/0000-0002-6157-0504

\section{References}

Agha, H., S. Feldman, A. Khalidi, and Z. Schiff. 2003. Track Two diplomacy: Lessons from the Middle East. Cambridge, MA: The MIT Press.

Allen, N., and T. Sharp. 2017. Process peace: A new evaluation framework for Track Two diplomacy. International Negotiation 22, no. 1: 92-122. doi:10.1163/15718069-12341349.

Azar, E.E. 1990. The management of protracted social conflict: Theory and cases. England: Dartmouth.

Beaekgaard, M., J. Christensen, C.M. Dahlmann, A. Mathiasen, and N.B.G. Petersen. 2019. The role of evidence in politics: Motivated reasoning and persuasion among politicians. British Journal of Political Science 49, no. 3: 1117-40. doi:10.1017/S0007123417000084.

Blaydes, L., and J. De Maio. 2010. Spoiling the peace? Peace process exclusivity and political violence in North-Central Africa. Civil Wars 12, no. 1-2: 3-28. doi:10.1080/ 13698249.2010.484896.

Burton, J.W. 1969. Conflict and communication: The use of controlled communication in international relations. London: Macmillan.

Chataway, C.J. 2002. The problem of transfer from confidential interactive problem-solving: What is the role of the facilitator? Political Psychology 23, no. 1: 165-89. doi:10.1111/0162-895X.00276.

Chigas, D. 2007. Capacities and limits of NGOs as conflict managers. In Leashing the dogs of war: Conflict management in a divided world, ed. C.A. Crocker, F.O. Hampson, and P. Aall, 553-82. Washington, D.C.: USIP.

Chigas, D. 2014. The role and effectiveness of non-governmental third parties in peacebuilding. In Moving toward a just peace: The mediation continuum, ed. J.M. Fritz, 273-216. New York: Springer.

Cuhadar, E. 2009. Assessing transfer from Track Two diplomacy: The cases of water and Jerusalem. Journal of Peace Research 46, no. 5: 641-58. doi:10.1177/0022343309336706.

Cuhadar, E., and B.W. Dayton. 2012. Oslo and its aftermath: Lessons learned from Track Two diplomacy. Negotiation Journal 28, no. 2: 155-79. doi:10.1111/j.1571-9979.2012.00333.x.

Darby, J. 2008. Borrowing and lending in peace processes. In Contemporary peacemaking: Conflict, peace processes and post-war reconstruction, ed. R. Mac Ginty and J. Darby, 339-51. New York: Palgrave Macmillan.

Davidson, W.D., and J.V. Montville. 1981. Foreign policy according to Freud. Foreign Policy 45, no. 1: 145-57. doi:10.2307/1148317.

Davies, J., and E. Kaufman. 2003. Second track/ citizens' diplomacy: Concepts and techniques for conflict transformation. New York: Raowman \& Littlefield Publishers.

Democratic Progress Institute. 2012. DPI roundtable meeting: Constitution making in a divided society. London: Democratic Progress Institute. 
Democratic Progress Institute. 2015a. DPI roundtable meeting 'getting the process back on track'. London: Democratic Progress Institute.

Democratic Progress Institute. 2015b. Getting a process back on track- a continued conversation on international experiences. London: Democratic Progress Institute.

Democratic Progress Institute. 2016. DPI roundtable meeting: 'Keeping dialogue alive- how to get a process back on track in the aftermath of a major crisis?' The Irish experience from a gendered perspective. London: Democratic Progress Institute. Our focus areas. http://www.democraticprogress.org/our-focus-areas/

Diamond, L., and J. Mcdonald. 1996. Multi-track diplomacy: A systems approach to peace. Connecticut: Kumarian Press.

Diamond, L., and R.J. Fisher. 1995. Integrating conflict resolution training and consultation: A Cyprus example. Negotiation Journal 11, no. 3: 287-301. doi:10.1111/j.1571-9979.1995. tb00070.x.

Dilek, E., 2019. Reconsidering hybridity: The selective use of international norms in Turkey's resolution/peace process. PhD diss., Bilkent University.

Druckman, J.N. 2012. The politics of motivation. Critical Review 24, no. 2: 199-216. doi:10.1080/ 08913811.2012.711022.

Fisher, R. 1997. Interactive conflict resolution. Syracuse, NY: Syracuse University Press.

Fisher, R.J. 2005. Analyzing successful transfer effects in interactive conflict resolution. In Paving the way: Contributions of interactive conflict resolution to peacemaking, ed. R.J. Fisher, 1-18. Oxford: Lexington Books.

Fisher, R.J., and L. Keashly. 1991. The potential complementarity of mediation and consultation within a contingency model of third party intervention. Journal of Peace Research 28, no. 1: 29-42. doi:10.1177/0022343391028001005.

Gillespie, J.J., L.L. Thompson, J. Lowenstein, and D. Gentner. 1999. Lessons from analogical reasoning in the teaching of negotiation. Negotiation Journal 15, no. 4: 363-71. doi:10.1111/ j.1571-9979.1999.tb00734.x.

Hazleton, W.A. 2013. Look at Northern Ireland: Leassons best learned at home. In Lessons from the Northern Ireland peace process, ed. T.J. White, 34-60. Madison: The University of Wisconsin Press.

Jones, P. 2015. Track Two diplomacy in theory and practice. Stanford: Stanford University Press.

Kadıoğlu, A. 2019. The Oslo talks: Revealing the Turkish government's secret negotiations with the PKK. Studies in Conflict and Terrorism 42, no. 10: 915-33. doi:10.1080/ 1057610X.2018.1430658.

Kaye, D.D. 2007. Talking to the enemy: Track Two diplomacy in the Middle East and South Asia. Pittsburgh: RAND Corporation.

Kelman, H.C. 1979. An interactional approach to conflict resolution and its application to the Israeli-Palestinian breakthrough. International Interactions 6: 99-122. doi:10.1080/ 03050627908434527.

Kelman, H.C. 1996. The interactive problem-solving approach. In Managing global chaos: Sources of and responses to international conflict, ed. C.A. Crocker and P. Aall, 501-19. Washington D. C.: USIP Press.

Kelman, H.C. 1997. Group processes in the resolution of international conflicts: Experiences from the Israeli-Palestinian case. American Psychologist 52, no. 3: 212-20. doi:10.1037/0003066X.52.3.212.

Kelman, H.C. 2006. The problem-solving workshop in conflict resolution. In Conflict resolution, ed. D. Druckman and P.F. Diehl, 78-107. London: SAGE Publications.

Knight, M., and A. Özerdem. 2004. Guns, camps and cash: Disarmament, demobilization and reinsertion of former combatants in transitions from war to peace. Journal of Peace Research 41, no. 4: 499-516. doi:10.1177/0022343304044479.

Kunda, Z. 1990. The case for motivated reasoning. Psychological Bulletin 108, no. 3: 480-98. doi:10.1037/0033-2909.108.3.480.

Lederach, J.P. 1997. Sustainable reconciliation in divided societies. Washington D.C.: USIP Press. 
Lederach, J.P. 1999. Building peace: Sustainable reconciliation in divided societies. Washington D. C.: United States Institute of Peace Press.

Lowenstein, J., L.L. Thompson, and D. Gentner. 2003. Analogical learning in negotiation teams: Comparing cases promotes learning and transfer. Academy of Management Learning and Education 2, no. 2: 119-27. doi:10.5465/amle.2003.9901663.

Mitchell, C., and M. Banks. 1996. Handbook of conflict resolution: The analytical problem-solving approach. New York: Pinter.

Mitchell, D. 2020a. Comparative consultation: The theory and practice of 'sharing lessons' between peace processes. Cooperation and Conflict 56, no. 1: 65-82.

Mitchell, D. 2020b. Learning from a peace process: Theory, practice, and the case of Northern Ireland. Government and Opposition (online first publication): 1-17. doi:10.1017/gov.2020.6.

Nadler, J., L.L. Thompson, and L. Van Boven. 2003. Learning negotiation skills: Four models of knowledge creation and transfer. Management Science 49, no. 4: 529-40. doi:10.1287/ mnsc.49.4.529.14431.

Nan, S.A. 2005. Track one-and-a-half diplomacy: Contributions to Georgian-South Ossetian peacemaking. In Paving the way: Contributions of interactive conflict resolution to peacemaking, ed. R.J. Fisher, 161-74. Oxford: Lexington Books.

Paffenholz, T., and C. Spurk. 2010. A comprehensive analytical framework. In Civil society \& peacebuilding: A critical assessment, ed. T. Paffenholz, 65-76. London: Lynne Rienner.

Pearson D'estrée, T. 2009. Problem-solving approaches. In The sage handbook of conflict resolution, ed. J. Bercovitch, V. Kremenyuk, and W.I. Zartman, 143-71. London: SAGE.

Rouhana, N.N. 2000. Interactive conflict resolution: Issues in theory, methodology, and evaluation. In International conflict resolution after the Cold War, ed. P.C. Stern and D. Druckman, 294-337. Washington, D.C.: National Academy Press.

Saunders, H.H. 2000. Interactive conflict resolution: A view for policy makers on making and building peace. In International conflict resolution after the Cold War, ed. P.C. Stern and D. Druckman, 251-93. Washington D.C.: National Academy Press.

Uluğ, Ö.M., and C.J. Cohrs. 2016. An exploration of lay people's Kurdish conflict frames in Turkey. Peace and Conflict: Journal of Peace Psychology 22, no. 2: 109-19. doi:10.1037/ pac0000165.

Uluğ, Ö.M., and C.J. Cohrs. 2017. How do experts differ from politicians in understanding a conflict? A comparison of track I and track II actors. Conflict Resolution Quarterly 35, no. 2: 147-72. doi:10.1002/crq.21208.

\section{Interviews}

\begin{tabular}{llll}
\hline Index & \multicolumn{1}{c}{ Position of the Interviewee } & Date of Interview & Location of Interview \\
\hline 1 & WPC Member & 1 October 2015 & Istanbul \\
2 & WPC Member, Former JDP MP & 7 October 2015 & Ankara \\
3 & Former JDP MP & 14 October 2015 & Ankara \\
4 & WPC Member, Representative of Human Rights Association & 16 October 2015 & Ankara \\
5 & WPC Member, Professor of Law & 28 October 2015 & Ankara \\
6 & WPC Member, Former JDP MP & 30 October 2015 & Ankara \\
7 & WPC Member, Journalist & 6 November 2015 & Istanbul \\
8 & WPC Member, Journalist, Former TESEV Executive Board Member & 16 November 2015 & Istanbul \\
9 & PDP MP & 30 November 2015 & Ankara \\
10 & JDP MP & 1 December 2015 & Ankara \\
11 & WPC Member, Journalist & 9 December 2015 & Istanbul \\
12 & WPC Member, PDP MP & 14 December 2015 & Ankara \\
13 & WPC Member, Civil Society Actor & 19 January 2016 & Istanbul \\
14 & Journalist & 20 January 2016 & Istanbul \\
15 & PDP MP & 2 February 2016 & Ankara \\
16 & DPI Turkey Program Representative & 2 August 2017 & Skype Interview \\
\hline
\end{tabular}

